\title{
Enhanced food-chain transfer of copper from a diet of copper-tolerant estuarine worms
}

\author{
P. S. Rainbow ${ }^{1, *}$, A. Geffard ${ }^{2}$, A.-Y. Jeantet ${ }^{3}$, B. D. Smith ${ }^{1}$, J. C. Amiard ${ }^{2}$, \\ C. Amiard-Triquet ${ }^{2}$ \\ ${ }^{1}$ Department of Zoology, The Natural History Museum, Cromwell Road, London SW7 5BD, UK \\ ${ }^{2}$ CNRS1117, ISOMer, SMAB (Insitut des Substances et des Organismes de la Mer, Substances Marines à Activité Biologique), \\ 2 rue de la Houssinière, BP 92208, 44322 Nantes Cedex 3, France \\ ${ }^{3}$ Equipe de Cytophysiologie analytique, Université Pierre et Marie Curie, 12 rue Cuvier, 75005 Paris, France
}

\begin{abstract}
The population of the infaunal, littoral polychaete worm Nereis (Hediste) diversicolor at the top of Restronguet Creek, England, an estuary with very high sediment concentrations of trace metals, is tolerant to copper. These worms accumulate abnormally high body copper concentrations in comparison to control worms (Blackwater Estuary, England), 68\% of the accumulated copper being bound in metal-rich granules. We show that sufficient of the extra copper accumulated in Restronguet Creek $N$. diversicolor is trophically available to another polychaete worm, $N$. virens, acting as predator, and brings about high accumulated copper concentrations in the latter worm. Electron microscopy with microanalysis has shown that copper detoxified in Cu-rich granules in the Restronguet Creek worms passes through the gut of the predator without apparent change in elemental composition. The trophically available copper in the Restronguet Creek worms may be in soluble form or bound to other cellular material. Ingestion of the Restronguet Creek worms will deliver an extraordinarily high (and potentially toxic) challenge to predators, including fishes and birds, feeding on $N$. diversicolor.
\end{abstract}

KEY WORDS: Trace metals • Food-chain transfer • Nereis diversicolor • Copper • Tolerance • Trophically available metal

\section{INTRODUCTION}

Trace metals accumulated by an aquatic invertebrate have the potential to be taken up and accumulated by a predator after assimilation in the alimentary tract, with the further potential to be transferred higher up a food chain with possible toxic effects. Furthermore it is now being realised that the dietary source of metal may offer the major route of metal uptake to many aquatic invertebrates (Wang \& Fisher 1999a,b, Rainbow \& Wang 2001, Wang 2002).

Invertebrates living in estuaries with high availabilities of trace metals use physiological mechanisms to cope with the uptake of atypically high quantities of these potentially toxic metals (Rainbow et al. 1999, Nassiri et al. 2000). In extreme circumstances, these toxic metal availabilities may be so high as to bring about the selection of local populations with metal tolerance (Luoma 1977, Klerks \& Weis 1987). Indeed, the presence of a metal-tolerant population of an organism in a particular habitat is evidence that toxic metal availabilities there are of ecotoxicological significance (Luoma 1977).

Restronguet Creek is a branch of the Fal Estuary System, Cornwall, England, receiving discharge from the Carnon River, draining a region with a long history of mining for metals (Dines 1969, Bryan \& Gibbs 1983). Sediments of Restronguet Creek correspondingly contain extraordinarily high levels of $\mathrm{As}, \mathrm{Cd}, \mathrm{Cu}, \mathrm{Fe}, \mathrm{Mn}$ and Zn (Bryan \& Gibbs 1983, Bryan et al. 1987, Berthet et al. 2003). The presence in Restronguet Creek of populations of invertebrates with tolerance to copper and zinc (Bryan \& Gibbs 1983) corroborates the concept that the local bioavailabilities of these 2 metals are eco- 
toxicologically significant. Thus the population of the common estuarine polychaete Nereis (Hediste) diversicolor in the upper reaches of Restronguet Creek has been found to be tolerant to both copper and zinc (Bryan \& Hummerstone 1971, 1973, Bryan \& Gibbs 1983, Grant et al. 1989, Hateley et al. 1989, Mouneyrac et al. 2003).

Many invertebrates have trace metal accumulation patterns that involve the detoxified storage of accumulated metal (Rainbow 2002). The copper-tolerant population of Nereis diversicolor in Restronguet Creek has an atypically high rate of copper accumulation with an associated high rate of copper detoxification (Bryan \& Hummerstone 1971, Bryan 1974, 1976). The total accumulated copper concentration of these worms can be as high as $3940 \mathrm{\mu g} \mathrm{Cu} \mathrm{g}^{-1}$ dry weight (DW) in comparison to less than $50 \mathrm{\mu g} \mathrm{Cu} \mathrm{g}^{-1} \mathrm{DW}$ in worms from uncontaminated sites (Berthet et al. 2003). Here we address the question as to whether this high accumulated concentration of copper, a potential toxin in high availabilities, is available to a predator when Restronguet Creek worms enter estuarine food chains.

The chemical form of detoxified storage of accumulated trace metal has a significant effect on the potential assimilation of that metal by a predator (Wang \& Fisher 1999b). Nott \& Nicolaidou (1990) have shown that the bioavailability to neogastropod predators of trace metals in detoxified metalliferous granules in barnacle and gastropod prey varies between metals and between granule type; metals were less available in phosphate granules than in carbonate granules. Nott \& Nicolaidou (1994) investigated the trophic transfer of metals from the digestive gland of 3 gastropod molluscs as prey tissue to the hermit crab Clibanarius erythropus. The availability of a metal in the mollusc tissue was affected by both the type of chemical binding and the nature of intracellular compartmentalisation resulting from detoxification processes in the gastropod digestive gland. Metals in membranebound phosphate granules $(\mathrm{Mn}, \mathrm{Ni}, \mathrm{Zn})$, lysosomes (also $\mathrm{Mn}, \mathrm{Ni}, \mathrm{Zn}$ ) and membrane-bound sulphur-rich granules $(\mathrm{Cu})$ were less available to consumers than cadmium, which was associated with sulphur but free in the cytosol (Nott \& Nicolaidou 1994).

Similarly the physicochemical form of accumulated cadmium in the oligochaete worm Limnodrilus hoffmeisteri is critical in the assimilation of the cadmium by the predator, in this case the decapod crustacean Palaemonetes pugio (Wallace \& Lopez 1996, 1997, Wallace et al. 1998). Cadmium in a population of cadmium-tolerant worms in Foundry Cove, Hudson River, New York, was predominantly stored in biologically unavailable metal-rich granules. However, accumulated cadmium concentrations in these tolerant worms were so high that a greater absolute amount of cad- mium was present in soluble form bound to the detoxificatory protein metallothionein (MT) (and therefore available to the predator) than in non-resistant worms, in spite of the latter worms storing all their (lower concentration of) accumulated cadmium as MT (Wallace et al. 1998). It has been proposed, therefore, that only metal bound to the soluble fraction in prey is available to higher trophic levels (Wallace \& Lopez 1996).

We have, therefore, also investigated the link between any trophic transfer of copper and the distribution of accumulated copper in the prey between soluble and insoluble components. We have confirmed recently that much of the accumulated copper in the copper-tolerant Restronguet Creek worms is in insoluble form, being associated with sulphur in electrondense deposits in the epicuticle and the epithelium of the body wall (Mouneyrac et al. 2003). The question remains therefore as to whether this high concentration of accumulated copper is in a form that is bioavailable to a predator.

We therefore fed Nereis diversicolor from the copper-tolerant population in Restronguet Creek and the same species from a non-tolerant population in a 'control' estuary, Blackwater Estuary, Essex, England, to a predator, another polychaete worm Nereis virens, and followed the comparative trophic transfer of accumulated copper from prey to predator.

\section{MATERIALS AND METHODS}

Collection. Nereis diversicolor were collected by hand from intertidal mudflats (upper $20 \mathrm{~cm}$ sediment depth) in the Blackwater Estuary $\left(51^{\circ} 44^{\prime} 08^{\prime \prime} \mathrm{N}, 00^{\circ} 41^{\prime} 34^{\prime \prime} \mathrm{E}\right)$ on 24 June 2002, and in Restronguet Creek $\left(50^{\circ} 12^{\prime} 36^{\prime \prime} \mathrm{N}, 05^{\circ} 05^{\prime} 41^{\prime \prime} \mathrm{W}\right)$ on 26 June 2002 and 20 January 2003, and transported back to the laboratory on the day of collection in cool boxes in sediment from the collection site. The worms were kept in the sediment from the site of origin covered by artificial seawater (TMN-Tropic Marin Neu, Tropicarium Buchschlag, Dreieich, Germany) at a salinity of 16 at $10^{\circ} \mathrm{C}$ for a few days. Worms were then placed in TMN at 16 salinity for $2 \mathrm{~d}$ without sediment to allow depuration of the gut before they were frozen for use in feeding experiments or for later analysis for metals.

Feeding experiments. Nereis virens were purchased from SEABAIT, Ashington, Northumberland, where they are reared commercially, and held at $10^{\circ} \mathrm{C}$ for a few days before being separated individually into acidwashed $100 \mathrm{ml}$ beakers with $50 \mathrm{~g}$ acid-washed sand (Merck) and $50 \mathrm{ml} \mathrm{TMN}$ at a salinity of 16 at either 10 or $15^{\circ} \mathrm{C}$. Seven $N$. virens were frozen for metal analysis as initials and the remainder were fed twice daily with thawed sections (ca. $0.5 \mathrm{~cm}$ long) of $N$. diversicolor 
from either the Blackwater Estuary or from Restronguet Creek (June 2002 collections) for up to $35 \mathrm{~d}\left(15^{\circ} \mathrm{C}\right)$ or $50 \mathrm{~d}\left(10^{\circ} \mathrm{C}\right)$. The number of meals and the fresh weight consumed by the predatory worms were recorded. The large number of pieces of prey worms consumed by each predatory worm over the period of the experiments was considered sufficient to allow for potential differences in amounts of copper ingested that would result from variability in copper concentrations of prey worms. We collected $7 \mathrm{~N}$. virens on Days 7, 14, 28 and 35 or 50, that had not been fed on the collection day, and stored them frozen for later metal analysis.

Copper analysis. Nereis virens and $N$. diversicolor collected in June 2002 from each site that had been frozen for metal analysis (see first subsection above) were subsequently dried to constant weight at $60^{\circ} \mathrm{C}$, and acid-digested in concentrated nitric acid (Aristar grade, Merck) at $100^{\circ} \mathrm{C}$. Each digest was made up to a known volume with double-distilled water and analysed for $\mathrm{Cu}$ content by atomic absorption spectrophotometry (AAS) on either a Varian SpectrAA 220 FS or a SpectrAA 55 spectrophotometer with background correction as appropriate. The Standard Reference Material Tort-2 (lobster hepatopancreas, National Research Council, Canada) was included in analyses. The mean measured $\mathrm{Cu}$ concentration in the reference material was $106 \pm 12 \mu \mathrm{g} \mathrm{g}^{-1}$ (95\% confidence limits [CL], $\mathrm{n}=5$ ), in good agreement with the certified copper concentration of $106 \pm 10 \mu \mathrm{g} \mathrm{g}^{-1}$ (95\% tolerance limits, $\mathrm{n}=5$ ). All metal concentrations are quoted in terms of dry weight.

Loss of copper during processing. We used 15 Nereis diversicolor collected from Restronguet Creek on 20 January 2003 to check the potential loss of accumulated copper from the worms as a result of processing for use as a food source in the feeding experiments. After depuration (see first subsection above), the worms were frozen, thawed and cut into 10 pieces (ca. $0.5 \mathrm{~cm}$ long) on clean filter paper. Worm pieces and the pieces of filter paper with any material 'lost' from each worm were analysed for copper content.

Subcellular partitioning. We divided 18 further Nereis diversicolor collected from Restronguet Creek on 20 January 2003 into 2 pools of 9 worms each. After depuration, freezing and thawing, each worm was cut into 10 pieces on clean filter paper as above. Pooled worm pieces (each about $2 \mathrm{~g}$ total wet weight) were homogenised and centrifuged according to the procedure previously used (Berthet et al. 2003) to separate the insoluble fraction of the tissues. The insoluble components recovered in this manner were digested with $1 \mathrm{~N} \mathrm{NaOH}$ and then centrifuged at $5000 \times g$ for $10 \mathrm{~min}$ as described by Wallace et al. (2003), allowing the separation of $\mathrm{Cu}$ associated either with metal-rich granules (pellet) or with tissue fragments and other cellular debris (supernatant). Each subsample was analysed for $\mathrm{Cu}$ by flame AAS as described in the foregoing subsection.

In vitro digestion of insoluble copper fraction. A further 4 replicate pools of 10 Nereis diversicolor collected from Restronguet Creek on 26 June 2002 were used to recover insoluble fractions as described in the foregoing subsection. The insoluble fraction (as a pellet) of each replicate was separated into 2 subsamples. The first subsample was used for direct estimation of copper content by AAS. The second subsample was exposed to a $\mathrm{pH}$ of 5.5 for $4 \mathrm{~h}$ by being placed in a solution of acetic acid, prior to a second centrifugation at $4300 \times g$ for $20 \mathrm{~min}$, and AAS analysis of $\mathrm{Cu}$ contents of supernatant ('digested' insoluble copper) and pellet ('undigested' insoluble copper). This $\mathrm{pH}$ was chosen to match the lowest gut $\mathrm{pH}$ reported in errant polychaetes by Michel \& De Villez (1978). The time period chosen was half the period between meals in the feeding experiment, the worms typically being very ready to eat approximately $8 \mathrm{~h}$ after the previous meal.

Electron microscopy. Nereis diversicolor from Restronguet Creek had previously been collected on 3 May 2000 and prepared for electron microscopy with energy-dispersive spectrophotometry (EDS) microanalysis. Tissues were fixed in 3\% glutaraldehyde buffered with $0.2 \mathrm{M} \mathrm{Na}$ cacodylate with $0.35 \mathrm{M}$ saccharose added, at $\mathrm{pH} 7.4$, for $1.5 \mathrm{~h}$ at $4^{\circ} \mathrm{C}$. Samples were post-fixed in $1 \%$ osmium tetroxide in water, dehydrated and embedded in Epon Araldite. Thin sections $(70 \mathrm{~nm})$ were collected onto copper grids, post-stained with uranyl acetate and lead citrate, and observed on a Phillips 201 transmission electron microscope (TEM). For microanalysis, samples were fixed in glutaraldehyde but not osmicated, thin-sectioned (80 to $100 \mathrm{~nm})$, collected onto titanium-carbon-coated grids, and left unstained. Xray EDS microanalysis was carried out on a Jeol JEM 2010 UHR TEM equipped with a PGT (Princeton Gamma Technology) Model IMIX PTS, at $200 \mathrm{kV}$, using 200 s counting periods, with a $70 \mu \mathrm{m}$ condenser diaphragm. Under these conditions, a very well localised (50 nm at $100000 \times$ magnification) but only qualitative in situ analysis was possible.

Nereis diversicolor collected from Restronguet Creek on 20 January 2003 were allowed to depurate (see first subsection above), frozen, thawed and cut into pieces (ca. $0.5 \mathrm{~cm}$ long) before being fed to individual $N$. virens at $15^{\circ} \mathrm{C}$ as described earlier. The faecal pellets produced by each $N$. virens feeding on the Restronguet Creek $N$. diversicolor were fixed and prepared for electron microscopy and EDS microanalysis as described for tissue samples. 
Table 1. Nereis spp. Copper concentrations (mean $\pm \mathrm{SD}$, $\mu \mathrm{g}^{-1}$ dry wt after $2 \mathrm{~d}$ depuration in laboratory) of whole worms (June 2002)

\begin{tabular}{|lccr|}
\hline Species & Site (UK) & Cu conc. & $\mathrm{n}$ \\
\hline Nereis diversicolor & Blackwater, Essex & $19.4 \pm 6.2$ & 7 \\
Nereis diversicolor & Restronguet Creek & $2763 \pm 1376$ & 10 \\
Nereis virens & Northumberland & $7.4 \pm 0.6$ & 6 \\
\hline
\end{tabular}

\section{RESULTS}

$\mathrm{Cu}$ concentrations measured in Nereis diversicolor collected from the Blackwater Estuary and Restronguet Creek in June 2002 are given in Table 1, together with the initial copper concentrations of $N$. virens used in experiments.

The process of preparing the prey worms for feeding to the predatory worms involved cutting the worms into smaller sections. It was necessary to check the degree of loss of copper from the prey worms during this process. The loss of copper from worm to absorbent filter paper during processing was $9.1 \pm$ $5.8 \%$ of the copper content of the prey worm.

Fig. 1 shows the accumulation of copper by Nereis virens feeding on $N$. diversicolor from either the Blackwater Estuary or Restronguet Creek at 10 or $15^{\circ} \mathrm{C}$. $N$. virens feeding on the copper-rich worms from Restronguet Creek had clearly assimilated and accumulated increased body loads of copper in comparison with those feeding on Blackwater worms with lower
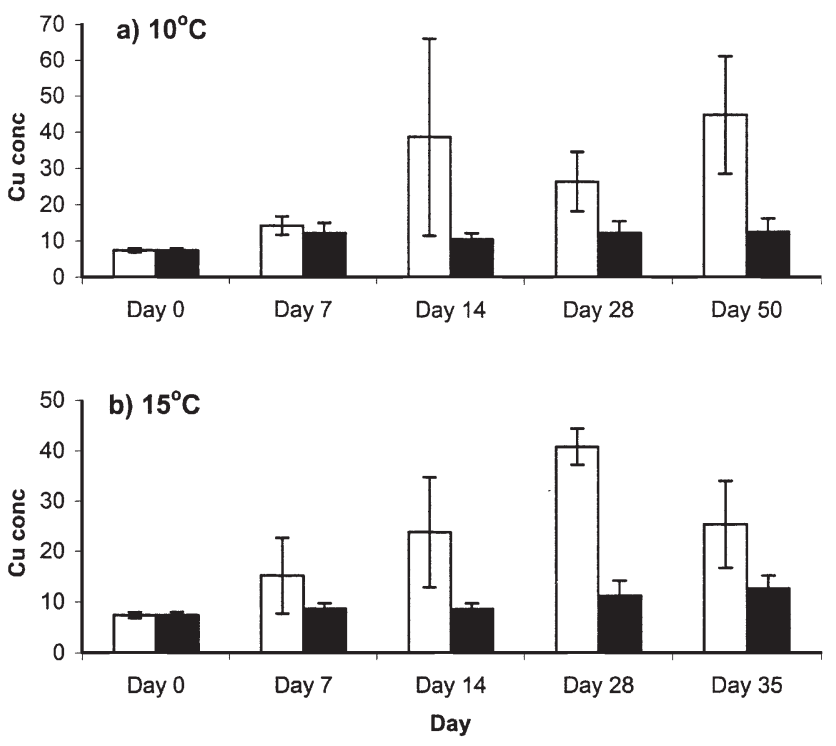

Fig. 1. Nereis virens. Accumulated concentrations of copper $\left(\mu \mathrm{g} \mathrm{g}^{-1}\right.$ dry wt $\pm 1 \mathrm{SD}, \mathrm{n}=6$ or 7$)$ in $N$. virens feeding on $N$. diversicolor from Restronguet Creek (white bars) or from Blackwater Estuary (black bars) for (a) up to $50 \mathrm{~d}$ at $10^{\circ} \mathrm{C}$ or (b) $35 \mathrm{~d}$ at $15^{\circ} \mathrm{C}$ body copper concentrations. There was considerable inter-individual variation in copper accumulation at both temperatures, preventing any clear conclusion on the comparative rates of copper accumulation at the 2 temperatures.

Records of the meals taken by Nereis virens over the experiment showed no significant differences in the number of meals taken per predatory worm when feeding on Restronguet Creek N. diversicolor or Blackwater $N$. diversicolor over the first $14 \mathrm{~d}\left(10^{\circ} \mathrm{C}\right)$ or the first $28 \mathrm{~d}\left(15^{\circ} \mathrm{C}\right)$. Cumulative feeding rates on the 2 diets did differ significantly, however-by Days 28 and 50 at $10^{\circ} \mathrm{C}$, and by Day 35 at $15^{\circ} \mathrm{C}$. The mean $( \pm 1 \mathrm{SD})$ cumulative feeding rates per individual predatory worm were $1.61 \pm 0.18$ and $2.09 \pm 0.12 \mathrm{mg} \mathrm{DW} \mathrm{d}^{-1}$ when feeding on Restronguet Creek and Blackwater $N$. diversicolor respectively at $10^{\circ} \mathrm{C}$ (50 d data), and $1.75 \pm 0.12$ and $1.92 \pm 0.19 \mathrm{mg} \mathrm{DW} \mathrm{d}^{-1}$ respectively at $15^{\circ} \mathrm{C}$ (35 d data). The feeding rate of $N$. virens was significantly greater on the diet of $N$. diversicolor from the Blackwater Estuary than on those from Restronguet Creek at both temperatures (time $t=6.01$ and 1.97 for $11 \mathrm{df}$ at $10^{\circ} \mathrm{C}$ [50 d data] and $15^{\circ} \mathrm{C}$ [35 d data] respectively). The increased copper accumulation from the Restronguet Creek prey is therefore not attributable to higher feeding rates.

The potential availability of insoluble copper to predators of Nereis diversicolor from Restronguet Creek was examined in worms processed in the same way as those fed to $N$. virens. Insoluble $\mathrm{Cu}$ was mainly present in metal-rich granules $(74.6 \%)$, whereas cellular debris accounted for $25.4 \%$. In vitro digestion of pellets containing insoluble $\mathrm{Cu}$ showed that at the lowest gut $\mathrm{pH}$ reported in errant polychaetes (5.5), only $6.7 \%$ of the insoluble $\mathrm{Cu}$ in the prey worms was solubilised.

Figs. $2 \& 3$ present electron micrographs and Fig. 4 associated EDS microanalytical spectra of electrondense granules in the tissues of Nereis diversicolor from Restronguet Creek and in faecal pellets of $N$. virens which had fed on these $N$. diversicolor. As described in detail by Mouneyrac et al. (2003), N. diversicolor from Restronguet Creek showed the presence of metal-rich granules in both the tegument and the intestine wall. The epidermal cells contained many mineralised lysosomes (Fig. 2a: enlarged in Fig. 3a,b). The EDS analyses showed that some contained $\mathrm{Fe}, \mathrm{P}, \mathrm{As}$ and $\mathrm{Pb}$ (Fig. 4a), whereas only $\mathrm{Cu}$ and $\mathrm{S}$ were detected in others (Fig. 4b). The epicuticle was loaded with numerous dense extra-cellular granules, which also contained only $\mathrm{Cu}$ and $\mathrm{S}$ (Mouneyrac et al. 2003). Mineralised lysosomes were also present in the intestinal cells (Fig. 2b). These intestinal lysosomes were loaded with microgranules containing $\mathrm{Fe}, \mathrm{P}, \mathrm{As}$ and $\mathrm{Pb}$, like those observed in the tegument (Mouneyrac et al. 2003). 
Fig. 2. Nereis diversicolor. Ultrastructure of tissues of worms from Restronguet Creek shown by transmission electron microscope after osmication and contrasted with uranyl acetate and lead citrate. (a) Tegument 30000×. Ep: epicuticle; arrow: extracellular granules; C: collagen; E: epidermal cells; Ly: mineralised lysosomes; Mi: microvilli of epidermal cells; (b) intestinal cells 14000×. M: mitochondria; Ly: mineralised lysosomes; Mi: microvilli of intestinal cells
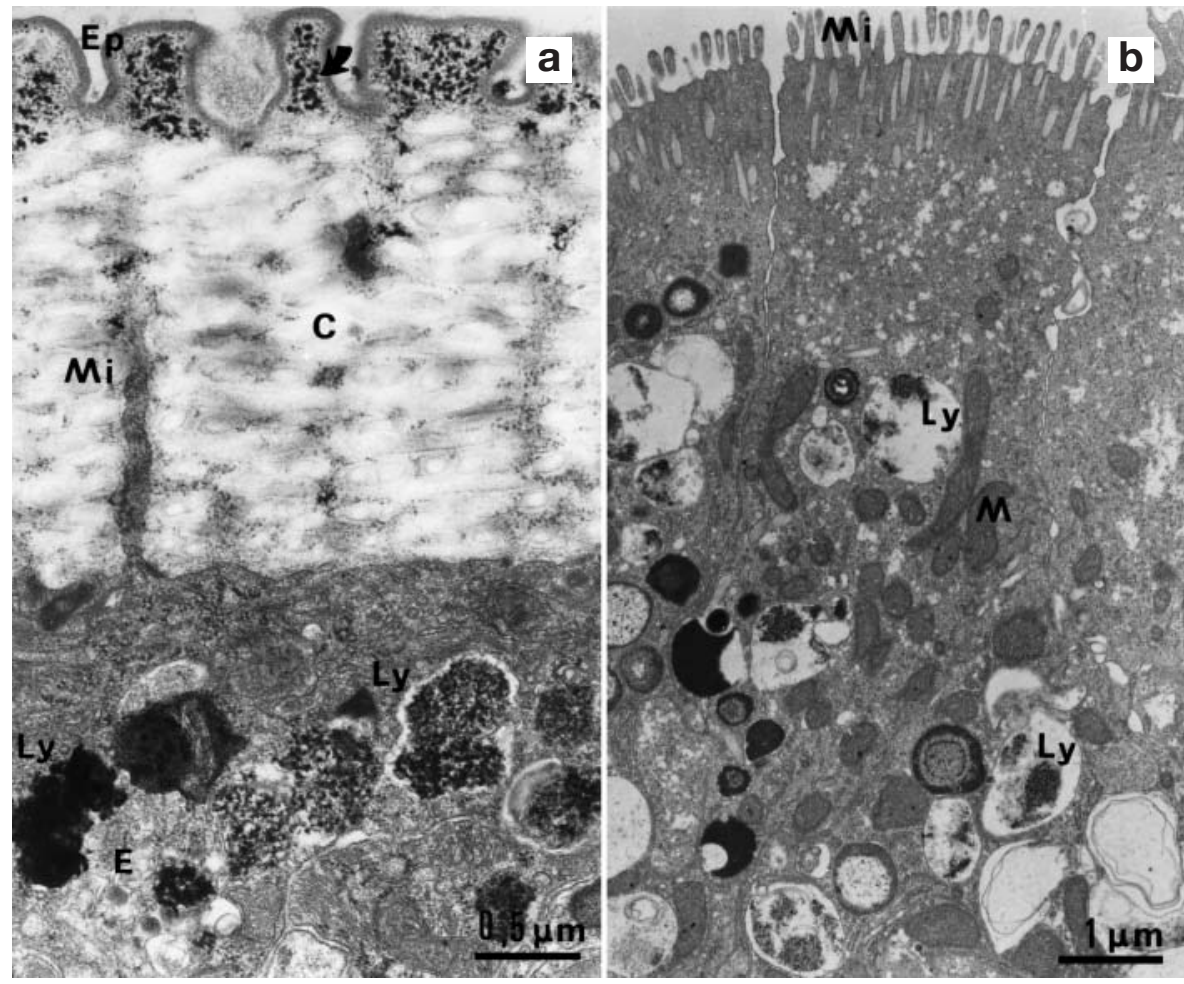
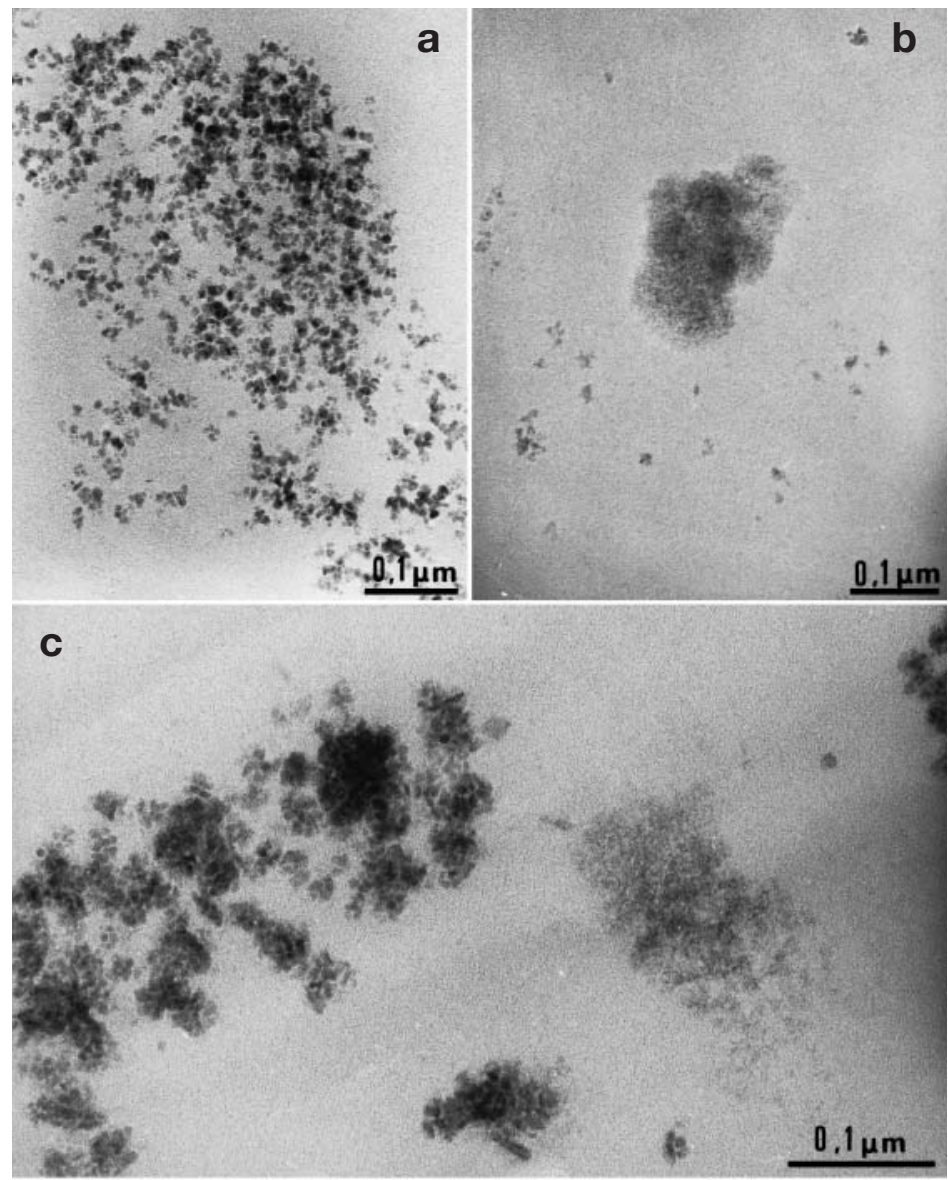

In the faecal pellets of Nereis virens which had fed on $N$. diversicolor from Restronguet Creek, granules rich in $\mathrm{Cu}$ and $\mathrm{S}$ were present (Figs. 3c \& 4c). They were morphologically indistinguishable from and had the same microanalytical spectra as each of 2 $\mathrm{Cu}$-rich granules identified in the prey worms, distinguishable only from their intracellular or extracellular position and location in the worms (Mouneyrac et al. 2003). A second type of granule was also found in $N$. virens faecal pellets which contained $\mathrm{Fe}, \mathrm{P}$, As and $\mathrm{Pb}$ (Figs. 3c \& 4d). These granules were indistinguishable from the granules from lysosomes in both epidermal and intestinal cells in Restronguet Creek $N$. diversicolor, the food source.

Fig. 3. Nereis spp. Enlargement of lysosomal content in situ in $(a, b)$ food species from Restronguet Creek and (c) in faeces of predator $N$. virens after feeding on Restronguet Creek $N$. diversicolor. Ultra-thin sections, non-osmicated and noncontrasted. (a) $\mathrm{Cu}$ - and S-rich granules of epidermal lysosomes (see spectrum Fig. 4b) 150000 $x_{i}$ (b) granules of epidermal lysosomes rich in $\mathrm{Fe}, \mathrm{P}, \mathrm{As}$, and $\mathrm{Pb}$ (see spectrum in Fig. 4a) $150000 x_{i}$ (c) granules of faecal pellets rich in $\mathrm{Cu}$ and $\mathrm{S}$ (on left) (see spectrum in Fig. 4c) or in $\mathrm{Fe}, \mathrm{P}, \mathrm{As}$, and $\mathrm{Pb}$ (on right) (see spectrum in Fig. 4d) $240000 \times$ 

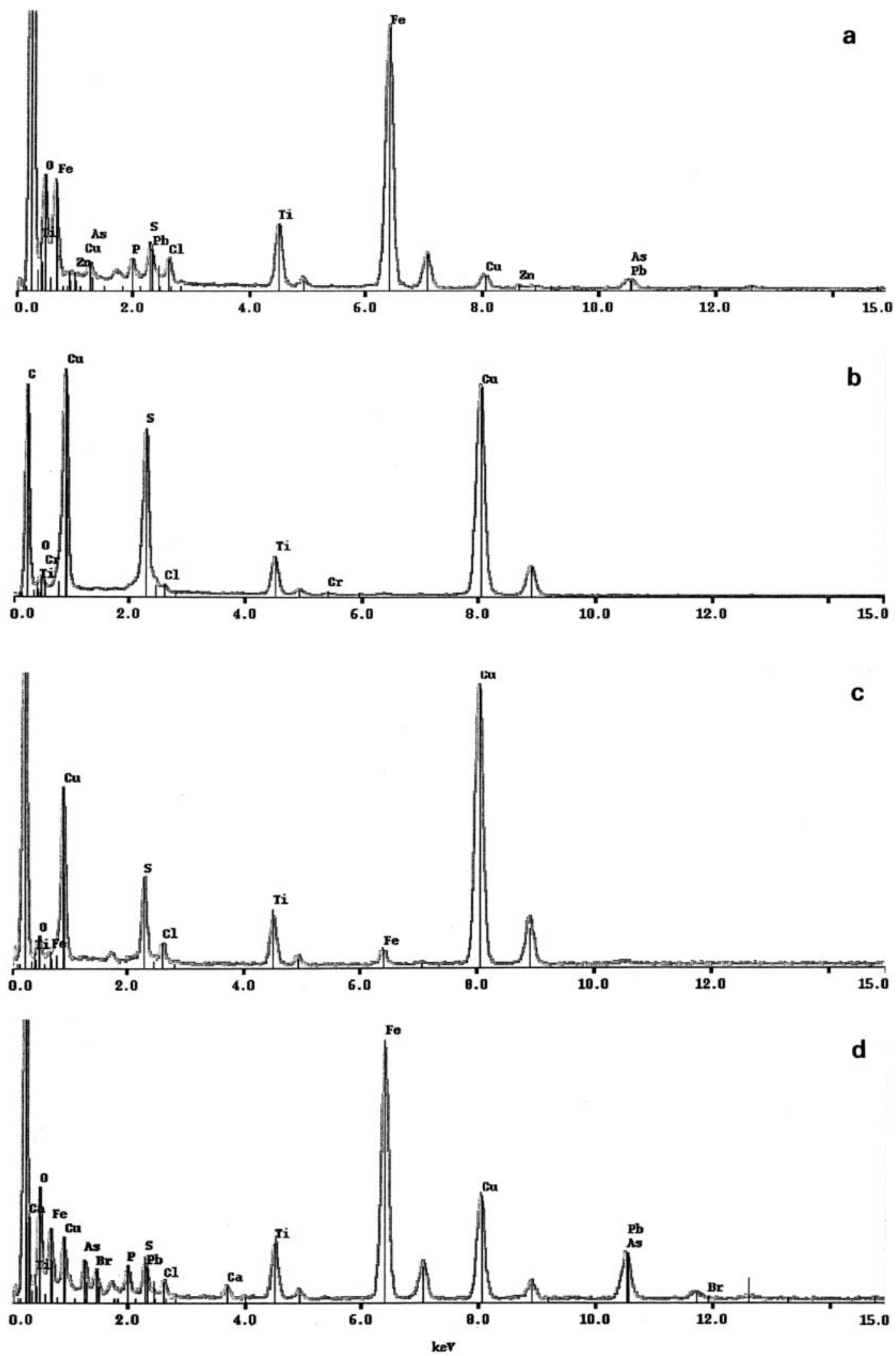

Fig. 4. Nereis spp. Energy-dispersive spectrophotometry (EDS) microanalysis of tegument of $N$. diversicolor and faeces of $N$. virens. Some elements such as $\mathrm{Cu}, \mathrm{Fe}, \mathrm{Zn}, \mathrm{As}, \mathrm{Pb}$, and Ti appear twice in spectrum because of $\mathrm{K} \alpha$ and L $\alpha \mathrm{X}$-ray emissions. Peaks of $\mathrm{C}$ and $\mathrm{O}$ on left of spectrum originate from organic matrix, $\mathrm{Ti}$ is emitted by the grid, $\mathrm{Cl}$ by the resin (epon). (a) Epidermal Fe-rich lysosomes; (b) epidermal Cu- and S-rich lysosomes; (c) faecal Cu- and S-rich granules; (d) faecal Fe-rich granules 
It can be concluded then that extra copper accumulated in Restronguet Creek Nereis diversicolor is bioavailable to another polychaete worm acting as a predator. Furthermore, copper detoxified in insoluble form in the Restronguet Creek $N$. diversicolor passes through the gut of the predator without apparent change in elemental composition.

\section{DISCUSSION}

This study has shown that it is possible for copper accumulated by worms in the copper-tolerant population of Nereis diversicolor in Restronguet Creek to be transferred to a predator. Since these worms accumulate extraordinarily high concentrations of copper from the copper-rich sediments of Restronguet Creek, this trophic transfer of copper is potentially of ecological significance.

The feeding experiments showed obvious copper accumulation in the predator Nereis virens over at least the first $14 \mathrm{~d}$ at both temperatures (Fig. 1), with the suggestion that accumulation in the predator reaches a plateau $\left(10^{\circ} \mathrm{C}\right)$ or declines $\left(15^{\circ} \mathrm{C}\right)$ thereafter. The kinetics of copper accumulation by $N$. virens will be pursued elsewhere (unpubl. data), but it is clear that copper in Restronguet Creek $N$. diversicolor is available to $N$. virens to a greater degree than in prey worms from the Blackwater, the control estuary.

As reported earlier (Bryan \& Hummerstone 1971, Bryan 1974, 1976, Berthet et al. 2003, Mouneyrac et al. 2003) and confirmed here (Table 1), Restronguet Creek Nereis diversicolor have very high accumulated copper concentrations. Berthet et al. (2003) found that $91 \%$ of this accumulated copper was in insoluble form in Restronguet Creek worms, while only $30 \%$ of the much lower accumulated copper content of Blackwater $N$. diversicolor was insoluble. Of this insoluble copper in Restronguet Creek worms, $74.6 \%$ was present in metal-rich granules (68\% of total body copper), the remaining insoluble copper being bound to cellular debris. As described by Mouneyrac et al. (2003) and confirmed here, extensive copper- and sulphur-rich granules are present in 2 body locations of Restronguet Creek $N$. diversicolor-extracellular granules in the epicuticle of the body wall (apparently the major copper store) and granules of identical composition in lysosomes of the epidermal cells below the epicuticle of the body wall.

Copper- and sulphur-rich granules were apparent in the faecal pellets of Nereis virens that had fed on Restronguet Creek $N$. diversicolor. These granules were indistinguishable morphologically and in elemental composition from the copper-rich granules identified above in intact prey. It was not possible to recognise cellular components such as lysosomal membranes in the faecal pellets, suggesting that these had been digested by the predator. Thus, the copperrich granules in the faecal pellets could be derived from either source (or more probably both sources) of copper-rich granules in the prey which had passed through the predator's gut undigested.

The other granule type found in the faecal pellets of the predator contained iron, calcium, lead and arsenic with phosphorus, and were indistinguishable (Figs. 3 \& 4) from granules described from lysosomes in body wall epidermal cells in Restronguet Creek Nereis diversicolor. These granules too appeared to have passed through the predator's gut undigested, but were not a possible source of assimilated copper. Mouneyrac et al. (2003) described a third metal-rich 'granule' from Restronguet Creek $N$. diversicolor: spherocrystals containing much zinc with phosphorus, calcium, lead and iron. These spherocrystals were not seen in the faecal pellets of $N$. virens, but it must be stressed that an exhaustive search for these spherocrystals was not carried out, since they do not contain copper.

Results from electron microscopy suggest that the copper accumulated and detoxified in insoluble form by Restronguet Creek Nereis diversicolor is not digestible by the predator. Results from the experiment assessing the potential digestibility of insoluble copper (91\% of total body copper) showed that at $\mathrm{pH} 5.5$ some $6.7 \%$ was solubilised in vitro. It cannot be totally excluded that some copper had been leached from the insoluble copper-rich granules during passage through the predatory worm's gut, but any such loss is not supported by the electron microscopy and EDS microanalysis data. Thus the fraction of insoluble copper solubilised in vitro was most probably derived from the copper bound to tissue fragments and other cellular debris $(25.4 \%$ of insoluble body copper, $23.1 \%$ of total body copper) in Restronguet Creek $N$. diversicolor, which remains a potential source of copper in the alimentary tract of the predator.

If the insoluble copper in granules in Restronguet Creek Nereis diversicolor is poorly assimilated and yet represents $91 \%$ of the copper content of these worms (Berthet et al. 2003), the question arises as to whether the soluble copper fraction can account for the observed increases in copper contents of the predators. Calculations are summarised in Table 2. These calculations are based on the measured copper concentrations in prey and predator (Table 1, Fig. 1), the mean dry weights of prey worms, the mean number of recorded meals eaten by each group of predatory worms and the mean dry weights of these predatory worms. Assumptions made are the percentage soluble components of accumulated copper in prey worms (9 and 30\% in Restronguet Creek and Blackwater 
Table 2. Nereis virens. Measured and calculated increases $\left(\mu \mathrm{g} \mathrm{g}^{-1}\right)$ in $\mathrm{Cu}$ concentrations in predatory $N$. virens feeding on $N$. diversicolor from Restronguet Creek and Blackwater Estuary for up to $50 \mathrm{~d}$. Calculations based on assimilation of $\mathrm{Cu}$ from ingested prey as follows: Total: total $\mathrm{Cu}_{\text {; }}$ Soluble: soluble $\mathrm{Cu}$ only; $6.7 \%$ insoluble: assimilation of $6.7 \%$ of insoluble $\mathrm{Cu}$ (Restronguet Creek prey only)

\begin{tabular}{|c|c|c|c|c|}
\hline \multirow[t]{2}{*}{ Day } & \multirow[t]{2}{*}{ Measured } & \multicolumn{3}{|c|}{ - Calculated - } \\
\hline & & Total & Soluble & $6.7 \%$ insoluble \\
\hline \multicolumn{5}{|l|}{$10^{\circ} \mathrm{C}$} \\
\hline \multicolumn{5}{|c|}{ Restronguet Creek } \\
\hline 7 & 6.8 & 142 & 12.8 & 8.6 \\
\hline 14 & 31.4 & 1020 & 91.9 & 62.2 \\
\hline 28 & 19.2 & 2313 & 249 & 141 \\
\hline 50 & 37.8 & 8206 & 740 & 501 \\
\hline \multicolumn{5}{|c|}{ Blackwater Estuary } \\
\hline 7 & 4.8 & 1.5 & 1.0 & \\
\hline 14 & 3.2 & 5.3 & 3.7 & \\
\hline 28 & 5.0 & 29.0 & 20.3 & \\
\hline 50 & 5.2 & 46.1 & 32.3 & \\
\hline \multicolumn{5}{|l|}{$15^{\circ} \mathrm{C}$} \\
\hline \multicolumn{5}{|c|}{ Restronguet Creek } \\
\hline 7 & 7.7 & 185 & 16.6 & 11.3 \\
\hline 14 & 16.4 & 508 & 45.8 & 31.0 \\
\hline 28 & 33.4 & 2062 & 186 & 126 \\
\hline 35 & 18.0 & 2292 & 207 & 140 \\
\hline \multicolumn{5}{|c|}{ Blackwater Estuary } \\
\hline 7 & 1.2 & 0.7 & 0.4 & \\
\hline 14 & 1.2 & 4.9 & 3.4 & \\
\hline 28 & 3.8 & 13.2 & 9.3 & \\
\hline 35 & 5.3 & 17.6 & 12.4 & \\
\hline
\end{tabular}

worms respectively), and that each meal contains $10 \%$ of the mean dry weight and mean copper content of the prey worms (i.e. each meal = one-tenth of $\mathrm{a}$ worm). The opportunity has also been taken to calculate the quantities of copper potentially available from Restronguet Creek prey worms if $6.7 \%$ of the copper in insoluble form were available to the predator. These data are lacking for Blackwater $N$. diversicolor.

There was sufficient soluble copper in the prey worms to account for the observed increases in copper concentration of the predators in each of the 4 experiments (Table 2). However, an amount of copper $(9.1 \%$ of total body $\mathrm{Cu}$ ) was lost from Restronguet Creek worms during processing, a figure equivalent to the percentage $(9 \%)$ of body copper in soluble form in Restronguet Creek Nereis diversicolor. It is also the case that $N$. virens could theoretically obtain enough copper from Restronguet Creek $N$. diversicolor to account for measured increases in copper accumulation, if $6.7 \%$ of insoluble copper could be digested and assimilated by the predator.

Thus trophic transfer of the copper from the Restronguet Creek Nereis diversicolor can be accounted for by assimilation of copper in soluble form only in the prey worms, and/or by the assimilation of some of the copper in insoluble form (probably bound to cell debris) in these worms. Wallace et al. (2003) have recently suggested that, in addition to any metal bound to protein, metal bound to organelles in the bivalves Macoma balthica and Potamocorbula amurensis may also be trophically available. We therefore plan further work to assess in more detail the exact nature of accumulated copper in $N$. diversicolor that is trophically available to a predator.

The decrease in feeding rate with time of Nereis virens feeding on $N$. diversicolor from Restronguet Creek in comparison with individuals feeding on Blackwater $N$. diversicolor deserves comment. It is possible that the predatory worms detect a 'taste' difference, thereby reducing metal uptake by behavioural avoidance activity (see Mason \& Jenkins 1995, Depta et al. 1999). The time taken for the difference in feeding rate to become apparent, however, suggests that this is not the case. Alternatively, the decrease in feeding rate may be a manifestation of a sublethal toxic effect of the contaminated diet on the behaviour of the predator, bearing in mind that contamination is not necessarily restricted to copper given the miscellany of toxic metals available in Restronguet Creek (Bryan \& Gibbs 1983).

The bioavailability of the copper in the Restronguet Creek population of Nereis diversicolor to a predator may have ecotoxicological consequences. N. diversicolor is a significant food source for many predators including fishes and birds (Evans et al. 1979, Summers 1980, Baird et al. 1985), and ingestion of Restronguet Creek worms will deliver an extraordinarily high (and potentially toxic) copper challenge to such predators.

Acknowledgements. Thanks are due to Cédric Fisson and Laurence Poirier for their contribution to compartmentalisation experiments. Anny Anglo and Lydia Massot prepared the samples for microanalysis and electron microscopy which were carried out at the Centre de Microscopie Électronique de l'IFR de Biologie Intégrative and the Service Inter-universitaire Assistance à la Recherche Université P. \& M. Curie, Paris, with the help of Patricia Beaunier. This research was supported in part by a grant from the CNRS France (PICS 1056).

\section{LITERATURE CITED}

Baird D, Evans PR, Milne H, Pienkowski MW (1985) Utilization by shorebirds of benthic production in intertidal areas. Oceanogr Mar Biol Annu Rev 23:575-597

Berthet B, Mouneyrac C, Amiard JC, Amiard-Triquet C and 5 others (2003) Response to metals of the polychaete annelid Hediste diversicolor, a key species in estuarine and coastal sediments. Arch Environ Contam Toxicol 45:468-478

Bryan GW (1974) Adaptation of an estuarine polychaete to sediments containing high concentrations of heavy metals. In: Vernberg FJ, Vernberg WB (eds) Pollution and physiology of marine organisms. Academic Press, New York, p 123-135 
Bryan GW (1976) Some aspects of heavy metal tolerance in aquatic organisms. In: Lockwood APM (ed) Effects of pollutants on aquatic organisms. Cambridge University Press, Cambridge, p 7-34

Bryan GW, Gibbs PE (1983) Heavy metals in the Fal Estuary, Cornwall: a study of long-term contamination by mining waste and its effects on estuarine organisms. Occas Publ Mar Biol Assoc UK 2:1-112

Bryan GW, Hummerstone LG (1971) Adaptation of the polychaete Nereis diversicolor to estuarine sediments containing high concentrations of heavy metals. I. General observations and adaptation to copper. J Mar Biol Assoc UK 51: 845-863

Bryan GW, Hummerstone LG (1973) Adaptation of the polychaete Nereis diversicolor to estuarine sediments containing high concentrations of zinc and cadmium. J Mar Biol Assoc UK 53:839-857

Bryan GW, Gibbs PE, Hummerstone LG, Burt GR (1987) Copper, zinc, and organotin as long-term factors governing the distribution of organisms in the Fal Estuary in southwest England. Estuaries 10:208-219

Depta B, Koscielniak A, Rozen A (1999) Food selection as a mechanism of heavy metal resistance in earthworms. Pedobiologia 43:608-614

Dines HG (1969) The metalliferous mining region of southwest England. Her Majesty's Stationery Office, London

Evans PR, Herdson DM, Knights PJ, Pienkowski MW (1979) Short-term effects of reclamation of part of seal sands, Teesmouth, England, UK on wintering waders and shelduck. 1. Shorebird diets, invertebrate densities and the impact of predation on the invertebrates. Oecologia 41: 183-206

Grant A, Hateley JG, Jones NV (1989) Mapping the ecological impact of heavy metals in the estuarine polychaete Nereis diversicolor using inherited metal tolerance. Mar Pollut Bull 20:235-238

Hateley JG, Grant A, Jones NV (1989) Heavy metal tolerance in estuarine populations of Nereis diversicolor. In: Ryland JS, Tyler PA (eds) Reproduction, genetics and distribution of marine organisms. Proc 23rd Eur Mar Biol Symp, Olsen \& Olsen, Fredensborg, p 379-385

Klerks PL, Weis JS (1987) Genetic adaptation to heavy metals in aquatic organisms: a review. Environ Pollut 45:173-205

Luoma SN (1977) Detection of trace contaminant effects in aquatic ecosystems. J Fish Res Board Can 34:436-443

Mason AZ, Jenkins KD (1995) Metal detoxication in aquatic organisms. In: Tessier A, Turner DR (eds) Metal speciation and bioavailability in aquatic systems. Wiley, Chichester, p 479-608

Michel C, De Villez EJ (1978) Digestion. In: Mill PJ (ed) Physiology of annelids, Chapter 13. Academic Press, p 509-554

Editorial responsibility: Otto Kinne (Editor), Oldendorf/Luhe, Germany
Mouneyrac C, Mastain O, Amiard JC, Amiard-Triquet C, Beaunier P, Jeantet AY, Smith BD, Rainbow PS (2003) Trace-metal detoxification and tolerance of the estuarine worm Hediste diversicolor chronically exposed in their environment Mar Biol 143:731-744

Nassiri Y, Rainbow PS, Amiard-Triquet C, Rainglet F, Smith BD (2000) Trace metal detoxification in the ventral caeca of Orchestia gammarellus (Crustacea: Amphipoda). Mar Biol 136:477-484

Nott JA, Nicolaidou A (1990) Transfer of metal detoxification along marine food chains. J Mar Biol Assoc UK 70: 905-912

Nott JA, Nicolaidou A (1994) Variable transfer of detoxified metals from snails to hermit crabs in marine food chains. Mar Biol 120:369-377

Rainbow PS (2002) Trace metal concentrations in aquatic invertebrates: why and so what? Environ Pollut 120:497-507

Rainbow PS, Wang WX (2001) Comparative assimilation of $\mathrm{Cd}, \mathrm{Cr}, \mathrm{Se}$, and $\mathrm{Zn}$ by the barnacle Elminius modestus from phytoplankton and zooplankton diets. Mar Ecol Prog Ser 218:239-248

Rainbow PS, Amiard-Triquet C, Amiard JC, Smith BD, Best SL, Nassiri Y, Langston W (1999) Trace metal uptake rates in crustaceans (amphipods and crabs) from coastal sites in NW Europe differentially enriched with trace metals. Mar Ecol Prog Ser 183:189-203

Summers RW (1980) The diet and feeding behaviour of the flounder Platichthys flesus (L.) in the Ythan estuary, Aberdeenshire, Scotland. Estuar Coast Mar Sci 11:217-232

Wallace WG, Lopez GR (1996) Relationship between the subcellular cadmium distribution in prey and cadmium transfer to a predator. Estuaries 19:923-930

Wallace WG, Lopez GR (1997) Bioavailability of biologically sequestered cadmium and the implications of metal detoxification. Mar Ecol Prog Ser 147:149-157

Wallace WG, Lopez GR, Levington JS (1998) Cadmium resistance in an oligochaete and its effect on cadmium trophic transfer to an omnivorous shrimp. Mar Ecol Prog Ser 172: $225-237$

Wallace WG, Lee BG, Luoma SN (2003) Subcellular compartmentalization of $\mathrm{Cd}$ and $\mathrm{Zn}$ in two bivalves. I. Significance of metal-sensitive fractions (MSF) and biologically detoxified metal (BDM). Mar Ecol Prog Ser 249: 183-197

Wang WX (2002) Interactions of trace metals and different marine food chains. Mar Ecol Prog Ser 243:295-309

Wang WX, Fisher NS (1999a) Delineating metal accumulation pathways for aquatic invertebrates. Sci Tot Environ 237/238:459-472

Wang WX, Fisher NS (1999b) Assimilation efficiencies of chemical contaminants in aquatic invertebrates: a synthesis. Environ Toxicol Chem 18:2034-2045

Submitted: September 11, 2003; Accepted: December 16, 2003 Proofs received from author(s): April 8, 2004 